\title{
Evaluation of biological efficacy of Trichoderma asperellum against tomato bacterial wilt caused by Ralstonia solanacearum
}

Narasimhamurthy Konappa ${ }^{1 *}$, Soumya Krishnamurthy ${ }^{3}$, Chandra Nayaka Siddaiah', Niranjana Siddapura Ramachandrappa ${ }^{1}$ and Srinivas Chowdappa ${ }^{2^{*}}$

\begin{abstract}
Bacterial wilt, caused by soilborne bacterium Ralstonia solanacearum, is one of the most severe diseases of tomato worldwide, and no successful control measures are available to date. In the present study, a sustainable alternative tool such as use of fungi from tomato rhizosphere is being utilized to combat the pathogen attack. The application of Trichoderma asperellum (T4 and T8) isolates delayed wilt development, effectively decreased the disease incidence, increased fruit yield, and improved plant growth promotion under field conditions. The T. asperellum treatment decreased the disease incidence by $51.06 \%$ (RS + T4) and 52.75\% (RS + T8) in Bhoomishettihalli (BH) and 47.21\% (RS + T4) and 46.83\% (RS + T8) in Madanahalli (MH) plots, respectively when compared with the pathogen-treated plot in year 2014. Correspondent decreases in year 2015 were 50.69\% (RS + T4) and 52.38\% (RS + T8) in BH and 48.18\% (RS + T4) and 49.22\% (RS + T8) in MH plots. In year 2014, T. asperellum (T4 and T8) treatment enhanced the yield with $5.45 \mathrm{t} /$ ha and $5.50 \mathrm{t} / \mathrm{ha}$ in $\mathrm{BH}$ plot and $6.66 \mathrm{t} / \mathrm{ha}$ and $6.93 \mathrm{t} / \mathrm{ha}$ in $\mathrm{MH}$ plot, respectively, when compared with infected plots. In year 2015, T. asperellum (T4 and T8) treatment enhanced the yield with $5.29 \mathrm{t} / \mathrm{ha}$ and $5.51 \mathrm{t} / \mathrm{ha}$ in BH plot and $5.82 \mathrm{t} / \mathrm{ha}$ and $5.66 \mathrm{t} / \mathrm{ha}$ in $\mathrm{MH}$ plot, respectively, when compared with infected plots. The disease control and yield enhancement were highest at T8, followed by T4. Increase in the level of peroxidase (POX), phenylalanine ammonium lyase (PAL),

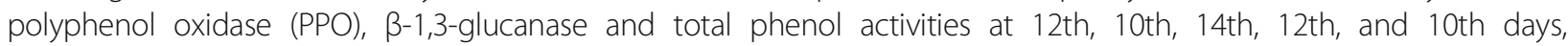
respectively, after pathogen inoculation was observed. This indicates the induction of plant resistance mechanism by $T$. asperellum against $R$. solanacearum in tomato plants under field conditions.
\end{abstract}

Keywords: Ralstonia solanacearum, Induced systemic resistance (ISR), Trichoderma asperellum, Tomato yield, Plant growth promoters

\section{Background}

Tomato (Lycopersicon esculentum) is one of the most widely cultivated vegetable crops worldwide. Vegetable crops are extremely prone to soilborne and root diseases causing huge losses in yield and its quality (Sharma et al. 2004). The main constraint to tomato production in many parts of the world is several plant diseases.

\footnotetext{
*Correspondence: n.murthy10@gmail.com; srinivasbub@gmail.com 'Department of Studies in Biotechnology, University of Mysore, Manasagangotri, Mysore, Karnataka 570 006, India

${ }^{2}$ Department of Microbiology and Biotechnology, Bangalore University, Jnanabharathi Campus, Bangalore, Karnataka 560 056, India

Full list of author information is available at the end of the article
}

Bacterial wilt is a destructive and prevalent soilborne disease that limits tomato production in the tropics, subtropics, and warm temperate regions of the world (Ramesh et al. 2014). Ralstonia solanacearum is one of the most severe quarantine important diseases of tomato worldwide. Its host range contains solanaceous species, leguminous species, a small number of monocotyledons, trees, shrubs, and certain ecotypes of the model plant Arabidopsis thaliana. The pathogen persists in soils, water, or reservoir plants for several years to form latent infections within native weeds contributing to the hard eradication of the bacterium (Avinash et al. 2016). 
Management of $R$. solanacearum, including use of resistant or tolerant varieties, cultural practices, chemical control, and biological control, are commonly employed methods to control bacterial wilt disease (Dalal et al. 1999). There are various beneficial microbes which have been completely implemented as biocontrol agents for inhibition of $R$. solanacearum under laboratory and/or greenhouse conditions, including Pseudomonas putida, P. fluorescens, Trichoderma spp., Bacteriophages, Streptomyces spp., Acinetobacter spp., Enterobacter spp., Bacillus spp. and Paenibacillus macerans (Vanitha et al. 2009 and Ling et al. 2010). Trichoderma isolates have strong antagonistic and mycoparasitic effects against phytopathogens and are therefore able to reduce disease severity in plants (Elsharkawy et al. 2012). The beneficial microorganisms have gained considerable attention as an ecofriendly and cost-effective platform for the stimulation of disease resistance through induced systemic resistance (ISR) and for the promotion of growth in plants for sustainable crop production (Abdelrahman et al. 2016). Trichoderma spp. induce plant growth by direct and indirect mechanisms (Zachow et al. 2016). Trichoderma spp. induce plant resistance against several phytopathogens, promote plant growth, and enhance photosynthetic activity of plants (Li et al. 2017). Presently, various reports indicate that Trichoderma induces systemic resistance by releasing not only proteins, but also secondary metabolites (Keswani et al. 2016).

Schonfeld et al. (2003) recorded a decrease in the $R$. solanacearum population in soil amended with decomposed organic fertilizer. The decomposed organic fertilizer or manure provides nutrients to the microbes, thus increases the biocontrol agent's ability and makes them extra competitive in the rhizosphere soil and on roots (Liu et al. 2012). Root colonization by biocontrol agents is considered a prerequisite and is directly connected to their effectiveness in controlling soilborne infections (Ji et al. 2008). The earlier studies have described that Trichoderma spp., Bacillus spp., and Klebsiella spp. enhanced colonize plant roots and rhizosphere, if they are applied to the soil with nutrient carrier, such as decomposed organic fertilizer or manure (Huang et al. 2011). Trichoderma spp. are now the greatest common fungal biocontrol agents that have been broadly studied and deployed throughout the world (Alka et al. 2017).

The objectives of the present study were to investigate biochemical responses in terms of defense enzymes and to evaluate the effectiveness of $T$. asperellum to induce systemic resistance against bacterial wilt in tomato plants, as well its effectiveness on bacterial wilt control or suppression of Ralstonia wilt under field conditions.

\section{Materials and methods}

Isolation and identification of microorganisms

Infected plant material and rhizosphere soil samples were collected from the wilted fields of tomato-growing areas of Karnataka. Ten virulent $R$. solanacearum strains were isolated from rhizosphere soil and shoot samples. The molecular identification of $R$. solanacearum isolates were confirmed based on 16S rRNA sequencing (Narasimha Murthy et al. 2016). Trichoderma spp. were isolated from healthy tomato plants' rhizosphere, using the soil dilution plate technique. Identification of Trichoderma spp. was further confirmed by National Fungal Culture Collection of India (NFCCI), Agharkar Research Institute and Pune. Among ten Trichoderma spp. two (T4 and T8) strains were selected for field experiments based on antibacterial and greenhouse studies against $R$. solanacearum (Narasimha Murthy et al. 2013).

\section{Preparation of bacterial inoculum}

One milliliter of $R$. solanacearum stock suspension was added to casamino acid peptone glucose (CPG) broth (1-g casamino acid, 10-g peptone, 5-g glucose per liter) and incubated at $28{ }^{\circ} \mathrm{C}$ for $48 \mathrm{~h}$ on rotary shaker at $150 \mathrm{rpm}$ (Kelman 1954). Culture broth was centrifuged at $12,000 \mathrm{rpm}$ for $10 \mathrm{~min}$ at $10{ }^{\circ} \mathrm{C}$. The bacterial pellet was resuspended in sterile distilled water and final concentration of suspension was set to $1 \times 10^{8} \mathrm{cfu} / \mathrm{ml}$, by spectrophotometrically adjusting to O.D $600 \mathrm{~nm}=0.1$ (Ran et al. 2005).

\section{Preparation of talc-based formulation}

The suspension of each Trichoderma spp. was prepared from 7-day-old culture on potato dextrose agar (PDA), using sterile distilled water. The fungal inoculum was prepared by flooding the culture with sterile distilled water and then rubbing its surface with a bent sterile glass rod. The suspension was filtered through four layers gauze bandage to separate the spores from the mycelia. The fungal concentration in each suspension was estimated by counting with the help of hemocytometer and was adjusted to $5 \times 10^{8}$ spores/ml (Rojo et al. 2007). One kilogram of talc powder was taken in a sterilized metal tray, and its $\mathrm{pH}$ was adjusted to neutral as above. Ten grams of carboxy methyl cellulose (CMC) was added to $1 \mathrm{~kg}$ of talc, mixed well, and the mixture was autoclaved for $30 \mathrm{~min}$ at $121^{\circ} \mathrm{C}$ and $15 \mathrm{lbs}$ pressure, each on two consecutive days. Five hundred milliliters of spore suspension were mixed with sterilized talc powder under aseptic conditions, and the spore concentration was adjusted to $5 \times 10^{8}$ spores $\mathrm{g}^{-1}$ with a sterile talc powder. After shade drying overnight, the formulation was packed in a polypropylene bag and sealed. The formulations were mixed with $50 \mathrm{~kg}$ of farmyard manure and incubated for 30 days before applying to each plot. 


\section{Field experiment}

Based on the previous in vitro and in vivo studies, under laboratory and greenhouse conditions (Narasimha Murthy and Srinivas 2012, and Narasimha Murthy et al. 2013), the most promising two $T$. asperellum isolates were selected for trial against the $R$. solanacearum under field conditions (Satish and Abhay 2016). The field experiment was conducted at the farmer's agricultural plots located in Bhoomishettihalli $(\mathrm{BH})\left(13^{\circ} 28^{\prime} 05.7^{\prime \prime}\right.$ $\left.\mathrm{N}, 78^{\circ} 04^{\prime} 57.7^{\prime \prime} \mathrm{E}\right)$ and Madanahalli $(\mathrm{MH})\left(13^{\circ} 16^{\prime}\right.$ $50.7^{\prime \prime} \mathrm{N}, 78^{\circ} 05^{\prime} 52.6^{\prime \prime}$ E) near Chintamani, Karnataka, India, during tomato growing season of March-June in 2014 and 2015. The experimental fields had been selected based on cultivation of tomatoes for several years and were naturally infested with $R$. solanacearum. Seeds of wilt susceptible tomato variety Arka Meghali were procured from Indian Institute of Horticultural Research (IIHR) Bangalore, India. Four-week-old tomato seedlings were uprooted from portrays and transplanted to experimental plots and treated with T. asperellum (T4 and T8) farmyard manure mixture ( $5 \mathrm{~g} /$ seedling) with spacing of $60 \times 90 \mathrm{~cm}$. The treatments were as shown as follows: (1) control (untreated seedlings), (2) T. asperellum alone (T4 and T8), (3) R. solanacearum alone, and (4) T. asperellum $+R$. solanacearum. The selected individual experimental plot area was of $25 \mathrm{~m}^{2}$ containing 14 rows with 80 or 100 plants per row, and the distance between rows was $50 \mathrm{~cm}$ (Narasimha Murthy et al. 2016). Buffer zones of $2 \mathrm{~m}$ without tomato seedlings were maintained between plots. Three replications were maintained for each treatment with 100 plants/ replication. The experiment was repeated thrice simultaneously in three different experimental plots of the fields. Seedlings were watered daily by drip irrigation, fertilized once with NPK fertilizer, farmyard manure (FYM) at $2.8 \mathrm{~kg} / \mathrm{m}^{2}$ and vermicompost at $0.5 \mathrm{~kg} / \mathrm{m}^{2}$. The NPK fertilizers consist of chemical fertilizers at the $\mathrm{N}: \mathrm{P}: \mathrm{K}$ ratio of $15: 7: 12$; urea containing $46.5 \mathrm{~N}$ was applied, $\mathrm{P}$ applied as $7 \%$ mono superphosphate $\mathrm{Ca}\left(\mathrm{H}_{2} \mathrm{PO} 4\right)_{2}$, and $\mathrm{K}$ as potassium sulfate containing $41.7 \%\left(\mathrm{~K}_{2} \mathrm{SO}_{4}\right)$. After 2 weeks of seedling transplantation, they were challenge inoculated by 48-h-old $R$. solanacearum suspension, $5 \mathrm{ml}$ per plant by soil drenching method. The completely wilted tomato plants in each treatment were observed, 1 week after challenge inoculation up to 90 days. Disease incidence was calculated as the percentage of plants that had completely wilted. Fruits per plant, fresh weight, dry weight, plant height, stem growth, and tomato yield was calculated tons per hectare ( $\mathrm{t} / \mathrm{ha}$ ) in each treatment, and total tomato yield was recorded at the end of the season. A total of four harvests were made at weekly intervals. The wilt incidence was evaluated when the infection emerged and calculated as the percentage of infected plants compared with the total number of growing plants in each plot. The percentage (\%) of disease incidence was calculated by using the following formula: \% of disease incidence $=$ no. of wilted plants in a plot/total no. of plants in a plot $\times 100$.

\section{Sample collection for biochemical analysis}

The leaf tissues of treated and untreated tomato plants were collected at different time intervals $(0,2,4,6,8,10$, $12,14,16,18$, and 20 days) after pathogen inoculation and stored in a deep freezer $\left(-80{ }^{\circ} \mathrm{C}\right)$ until used for biochemical analysis (Narasimha Murthy et al. 2016). Leaf tissues were homogenized by liquid nitrogen in a pre-chilled mortar and pestle. One gram of tomato leaf tissues was homogenized by $2 \mathrm{ml}$ of $0.1 \mathrm{M}$ sodium phosphate buffer $(\mathrm{pH} 7.0)$ at $4{ }^{\circ} \mathrm{C}$, and the homogenate was centrifuged for $20 \mathrm{~min}$ at $12,000 \mathrm{rpm}$. The supernatant was used as a crude extract for analyzing peroxidase (POX) (Hammerschmidt et al. 1982), polyphenol oxidase (PPO) (Mayer et al. 1965), and phenylalanine ammonia lyase (PAL) (Dickerson et al. 1984). As for the estimation of $\beta$-1,3-glucanase, $1 \mathrm{~g}$ of tomato leaf tissues was homogenized by $2 \mathrm{ml}$ of $0.1 \mathrm{M}$ sodium citrate buffer $(\mathrm{pH} 5.0)$ in a pre-chilled mortar and pestle, centrifuged, and supernatant was used for the estimation (Pan et al. 1991). The total phenol content was estimated as per the procedure given by Zieslin and Ben-Zaken (1993). The following treatments were included in the experiments: untreated control plants $(C)$, plants inoculated with $R$. solanacearum alone (T1), plants inoculated with $T$. asperellum alone (T2), and plants inoculated with $T$. asperellum and challenge inoculated with $R$. solanacearum (T3).

\section{Protein estimation}

Protein estimations of all the enzyme extracts were carried out by Lowry's method (Lowry et al. 1951) using bovine serum albumin as a standard.

\section{Native poly acrylamide gel electrophoresis analysis}

The isoforms profiles of peroxidase and polyphenol oxidase were estimated by discontinuous native polyacrylamide gel electrophoresis (PAGE) (Laemmli 1970). The protein extracts were prepared by homogenizing $1.0 \mathrm{~g}$ of leaf tissues with $2 \mathrm{ml}$ of $0.1 \mathrm{M}$ sodium phosphate buffer (pH 7.0) and centrifuged at 20,000 rpm for $15 \mathrm{~min}$ at $4{ }^{\circ} \mathrm{C}$. Samples $(80-\mu$ g protein) were loaded into $8 \%$ polyacrylamide gels (Sigma, USA). After electrophoresis, POX isoforms were observed by soaking the gels in staining solution containing $0.05 \%$ benzidine (Sigma-Aldrich, Mumbai, India) and $0.03 \% \mathrm{H}_{2} \mathrm{O}_{2}$ in acetate buffer (20 mM, pH 4.2) for $30 \mathrm{~min}$ in the dark, after which drops of $30 \% \mathrm{H}_{2} \mathrm{O}_{2}$ were added with constant shaking til the bands appeared (Nadolny and Sequeira 1980). For assessing the PPO isoform, the gels were equilibrated for 
$30 \mathrm{~min}$ in $0.1 \%$ 1,3-dihydroxyphenylalanine (DOPA) in $0.1 \mathrm{M}$ potassium phosphate buffer ( $\mathrm{pH}$ 7.0), followed by the addition of $10 \mathrm{mM}$ catechol in the same buffer. The addition of catechol was followed by gentle shaking, resulted in appearance of dark brown discrete protein bands indicative of PPO isozymes appeared in the gel (Jayaraman et al. 1987).

\section{Statistical analyses}

All data of field trial experiments were statistically analyzed, using Microsoft Excel ${ }^{\mathrm{m}}$ and SPSS (version 20.0). The data were subjected to analysis of variance (ANOVA), and the means were analyzed, using Duncan's new multiple range post test at $p \leq 0.05$.

\section{Results and discussion}

Field experiment for assessment of $T$. asperellum isolates to control of bacterial wilt

The characterization of $T$. asperellum antagonism against $R$. solanacearum was the initial step in assessing the biocontrol capacity of these agents. In a previous study, Trichoderma spp. were screened for antagonistic activity, seed germination, and plant growth promotion under greenhouse condition against $R$. solanacearum (Narasimha Murthy et al. 2013). In the present investigation, the two potential $T$. asperellum isolates, from the rhizosphere soil of tomato plants as biocontrol agents to control $R$. solanacearum, were assessed. Soil treatment with $T$. asperellum reduced the wilt disease incidence than the untreated control and also significantly enhanced the plant growth and tomato yield (Tables 1 and 2). The plant growth was assessed, as a total amount of fruits per plant, fresh weight, dry weight, plant height, stem growth, and tomato yield. In year 2014, the disease incidence in untreated control plots was nil in both plots. In $R$. solanacearum-infected $\mathrm{BH}$ and $\mathrm{MH}$ plots, the disease incidence ranged from 85.59 to $91.07 \%$ and 84.54 to $89.65 \%$, respectively. T. asperellum-treated plots showed an average of 36.43 and $40.08 \%$ disease incidence in $\mathrm{BH}$ and $\mathrm{MH}$ plots, respectively. The T. asperellum treatment decreased the disease incidence by $51.06 \%(\mathrm{RS}+\mathrm{T} 4)$ and $52.75 \%(\mathrm{RS}+\mathrm{T} 8)$ in $\mathrm{BH}$ and $47.21 \%(\mathrm{RS}+\mathrm{T} 4)$ and $46.83 \%$ (RS + T8) in $\mathrm{MH}$ plots, respectively. The tomato yield in untreated control plot of $\mathrm{BH}$ was $7.52 \mathrm{t} / \mathrm{ha}$ and $7.12 \mathrm{t} / \mathrm{ha}$ in $\mathrm{MH}$ plot. The tomato yield in $R$. solanacearum-infected $\mathrm{BH}$ plot was about 1.29 to $1.69 \mathrm{t} / \mathrm{ha}$ and, in $\mathrm{MH}$ plot, 1.23 to $1.76 \mathrm{t} / \mathrm{ha}$. $T$. asperellum isolate (T4 and T8)-treated plots yielded an average of 8.15 and $8.26 \mathrm{t} / \mathrm{ha}$ in $\mathrm{BH}$ and of 7.89 and $8.16 \mathrm{t} /$ ha of tomatoes in $\mathrm{MH}$, respectively. Thus, tomato yield increased by an average of 8.38 and $9.84 \%$ in $\mathrm{BH}$ and 10.82 and $14.61 \%$ in $\mathrm{MH}$ for $\mathrm{T} 4$ and $\mathrm{T} 8$ treatments, respectively, as compared with the untreated control plots (Fig. 1). Plots challenge inoculated with $R$. solanacearum and treated with T4 and T8 yielded an average of 6.27 and $6.36 \mathrm{t} / \mathrm{ha}$ in $\mathrm{BH}$ and 6.63 and $6.49 \mathrm{t} / \mathrm{ha}$ in $\mathrm{MH}$ plots, respectively. T. asperellum (T4 and T8) treatment enhanced the tomato yield by $5.45 \mathrm{t} / \mathrm{ha}$ and $5.50 \mathrm{t} / \mathrm{ha}$ in $\mathrm{BH}$ and $6.66 \mathrm{t} / \mathrm{ha}$ and $6.93 \mathrm{t} / \mathrm{ha}$, in $\mathrm{MH}$, respectively when compared with $R$. solanacearum-treated plots.

Table 1 Influence of T. asperellum on tomato plant growth, yield, and control of bacterial wilt under field conditions during the year 2014

\begin{tabular}{|c|c|c|c|c|c|c|c|c|c|c|c|c|c|c|}
\hline \multirow{2}{*}{$\begin{array}{l}\text { Treatments } \\
\text { Plots }\end{array}$} & \multicolumn{2}{|c|}{ Plant height $(\mathrm{cm})$} & \multicolumn{2}{|c|}{ Fresh weight (g) } & \multicolumn{2}{|c|}{ Dry weight (g) } & \multicolumn{2}{|c|}{ Stem growth $(\mathrm{cm})$} & \multicolumn{2}{|c|}{ No. of fruits/plant } & \multicolumn{2}{|c|}{ Yield (t/ha) } & \multicolumn{2}{|c|}{ Disease incidence (\% } \\
\hline & $\overline{\mathrm{BH}}$ & $\mathrm{MH}$ & $\overline{\mathrm{BH}}$ & $\mathrm{MH}$ & $\overline{\mathrm{BH}}$ & $\mathrm{MH}$ & $\mathrm{BH}$ & $\mathrm{MH}$ & $\overline{\mathrm{BH}}$ & $\mathrm{MH}$ & $\overline{\mathrm{BH}}$ & $\mathrm{MH}$ & $\overline{\mathrm{BH}}$ & $\mathrm{MH}$ \\
\hline Control & $58.23^{d}$ & $57.17^{c d}$ & $417.32^{h}$ & $415.76^{h}$ & $46.32^{c}$ & $43.45^{c}$ & $1.18^{\mathrm{e}}$ & $1.09^{d}$ & $43.25^{h}$ & $42.67^{h}$ & $7.52^{c}$ & $7.12^{c}$ & a & $0^{a}$ \\
\hline S1 & $36.45^{\mathrm{b}}$ & $35.65^{\mathrm{b}}$ & $168.21^{e}$ & $160.98^{\mathrm{e}}$ & $15.14^{\mathrm{a}}$ & $14.54^{\mathrm{a}}$ & $0.54^{d}$ & $0.52^{d}$ & $13.59^{e}$ & $13.43^{\mathrm{e}}$ & $1.44^{\mathrm{a}}$ & $1.32^{\mathrm{a}}$ & $91.07^{9}$ & $89.65^{9}$ \\
\hline 52 & $35.26^{a b}$ & $33.79^{\mathrm{a}}$ & $157.87^{\mathrm{abc}}$ & $156.67^{\mathrm{ab}}$ & $14.96^{\mathrm{a}}$ & $14.56^{\mathrm{a}}$ & $47^{\mathrm{ab}}$ & $0.51^{\mathrm{b}}$ & $15.15^{f}$ & $14.23^{f}$ & $1.65^{\mathrm{a}}$ & $1.45^{\mathrm{a}}$ & $89.18^{f}$ & $88.43^{f}$ \\
\hline 3 & $36.44^{\mathrm{ab}}$ & $34.56^{\mathrm{ab}}$ & $164.47^{d}$ & $159.34^{\text {cd }}$ & $14.89^{a}$ & $13.23^{\mathrm{a}}$ & $0.45^{\mathrm{a}}$ & $0.56^{\mathrm{ab}}$ & $13.89^{e}$ & $12.76^{e}$ & $1.54^{\mathrm{a}}$ & $1.55^{\mathrm{a}}$ & $88.54^{\mathrm{ef}}$ & $86.87^{\mathrm{ef}}$ \\
\hline 254 & $38.24^{\mathrm{ab}}$ & $32.54^{\mathrm{a}}$ & $156.76^{\mathrm{abc}}$ & $154.55^{\mathrm{b}}$ & $15.92^{\mathrm{a}}$ & $15.76^{\mathrm{a}}$ & $0.52^{\mathrm{abc}}$ & $0.54^{\mathrm{bc}}$ & $12.22^{\text {de }}$ & $11.23^{\text {de }}$ & $1.62^{\mathrm{a}}$ & $1.23^{\mathrm{a}}$ & $88.68^{\mathrm{ef}}$ & $87.23^{e f}$ \\
\hline 55 & $34.07^{\mathrm{a}}$ & $35.23^{b c}$ & $160.86^{c d}$ & $153.76^{\mathrm{ab}}$ & $15.8^{\mathrm{a}}$ & $14.55^{\mathrm{a}}$ & $0.36^{d}$ & $0.48^{\text {de }}$ & $9.89^{\mathrm{ab}}$ & $8.98^{\mathrm{ab}}$ & $1.29^{\mathrm{a}}$ & $1.16^{\mathrm{a}}$ & $88.29^{f g}$ & $84.65^{\mathrm{ef}}$ \\
\hline is6 & $34.92^{\mathrm{ab}}$ & $36.76^{c}$ & $155.32^{\mathrm{ab}}$ & $156.87^{\mathrm{ab}}$ & $5.75^{\mathrm{a}}$ & $15.78^{\mathrm{a}}$ & $0.48^{\mathrm{abc}}$ & $0.57^{d}$ & $12.77^{\text {de }}$ & $10.34^{e}$ & $1.54^{\mathrm{a}}$ & $1.43^{\mathrm{a}}$ & $87.12^{\mathrm{e}}$ & $87.87^{f}$ \\
\hline 7 & $35.30^{\mathrm{ab}}$ & $34.57^{b}$ & $158.54^{b c}$ & $157.54^{\mathrm{bc}}$ & $16.30^{a}$ & $15.83^{a}$ & $0.50^{b c}$ & $0.56^{\mathrm{ab}}$ & $8.55^{\mathrm{a}}$ & $13.76^{\mathrm{ef}}$ & $1.46^{\mathrm{a}}$ & $1.29^{\mathrm{a}}$ & $88.26^{\mathrm{ef}}$ & $85.45^{\mathrm{d}}$ \\
\hline RS8 & $33.89^{\mathrm{a}}$ & $35.43^{b}$ & $156.46^{\mathrm{ab}}$ & $159.48^{c}$ & $16.54^{\mathrm{a}}$ & $16.38^{\mathrm{a}}$ & $0.49^{\mathrm{abc}}$ & $0.54^{b c}$ & $11.60^{c d}$ & $12.48^{e}$ & $1.61^{\mathrm{a}}$ & $1.57^{\mathrm{a}}$ & $85.59^{d}$ & $87.78^{f}$ \\
\hline . & $36.37^{b}$ & $37.87^{c}$ & $153.23^{\mathrm{a}}$ & $152.93^{\mathrm{ab}}$ & $15.45^{\mathrm{a}}$ & $14.72^{\mathrm{a}}$ & $0.54^{b c d}$ & $0.59^{d}$ & $10.78^{\mathrm{bc}}$ & $12.12^{\mathrm{e}}$ & $1.69^{\mathrm{a}}$ & $1.54^{\mathrm{a}}$ & $89.60^{f}$ & $84.54^{\text {ef }}$ \\
\hline RS10 & $34.58^{\mathrm{ab}}$ & $36.62^{b}$ & $157.11^{\mathrm{abc}}$ & $156.78^{\mathrm{ab}}$ & $15.48^{\mathrm{a}}$ & $16.76^{\mathrm{a}}$ & $0.55^{\mathrm{cd}}$ & $0.60^{c d}$ & $12.27^{\text {de }}$ & $11.16^{\mathrm{de}}$ & $1.54^{\mathrm{a}}$ & $1.72^{\mathrm{a}}$ & $89.18^{f}$ & $89.54^{9}$ \\
\hline 4 & $74.10^{e}$ & $72.94^{e}$ & $647.95^{i}$ & $641.96^{h}$ & $49.29^{d}$ & $48.92^{d}$ & $1.38^{f}$ & $1.35^{f}$ & $52.53^{i}$ & $50.43^{i}$ & $8.15^{c}$ & $7.89^{\mathrm{cd}}$ & $0^{a}$ & $0^{\mathrm{a}}$ \\
\hline 8 & $74.17^{\mathrm{e}}$ & $72.52^{\mathrm{e}}$ & $685.07^{j}$ & $678.48^{j}$ & $50.21^{d}$ & $48.81^{d}$ & $1.43^{f}$ & $1.41^{f}$ & $55.29^{j}$ & $54.36^{j}$ & $8.26^{c}$ & $8.16^{d}$ & $0^{a}$ & $0^{\mathrm{a}}$ \\
\hline$+T 4$ & $48.76^{c}$ & $46.98^{d}$ & $386.65^{f}$ & $379.54^{f}$ & $34.63^{b}$ & $35.34^{b c}$ & $1.13^{\mathrm{e}}$ & $1.12^{\mathrm{e}}$ & $38.26^{9}$ & $37.65^{9}$ & $6.74^{\mathrm{b}}$ & $6.63^{b}$ & $37.27^{c}$ & $39.89^{c}$ \\
\hline$R S+T 8$ & $49.54^{c}$ & $46.56^{c}$ & $392.14^{9}$ & $385.76^{9}$ & $35.26^{\mathrm{b}}$ & $34.98^{b}$ & $1.15^{\mathrm{e}}$ & $1.14^{\mathrm{e}}$ & $39.18^{9}$ & $38.33^{9}$ & $6.79^{b}$ & $6.49^{b}$ & $35.58^{\mathrm{b}}$ & $40.27^{d}$ \\
\hline
\end{tabular}

Means of three replications, followed by the letters significantly different according to Duncan's multiple range tests (DMRT). Values with different alphabetical (a-j) superscripts in a column significantly different $(P \leq 0.05)$

RS Ralstonia solanacearum, T4 and T8 T. asperellum isolates, $B H$ Bhoomishettihalli, MH Madanahalli 
Table 2 Influence of T. asperellum on tomato plant growth, yield, and control of bacterial wilt under field conditions during the year 2015

\begin{tabular}{|c|c|c|c|c|c|c|c|c|c|c|c|c|c|c|}
\hline \multirow{2}{*}{$\begin{array}{l}\text { Treatments } \\
\text { Plots }\end{array}$} & \multicolumn{2}{|c|}{ Plant height $(\mathrm{cm})$} & \multicolumn{2}{|c|}{ Fresh weight (g) } & \multicolumn{2}{|c|}{ Dry weight (g) } & \multicolumn{2}{|c|}{ Stem growth $(\mathrm{cm})$} & \multicolumn{2}{|c|}{ No. of fruits/plant } & \multicolumn{2}{|c|}{ Yield (t/ha) } & \multicolumn{2}{|c|}{ Disease incidence (\%) } \\
\hline & $\mathrm{BH}$ & $\mathrm{MH}$ & $\mathrm{BH}$ & $\mathrm{MH}$ & $\mathrm{BH}$ & $\mathrm{MH}$ & $\mathrm{BH}$ & $\mathrm{MH}$ & $\mathrm{BH}$ & $\mathrm{MH}$ & $\mathrm{BH}$ & $\mathrm{MH}$ & $\mathrm{BH}$ & $\mathrm{MH}$ \\
\hline Control & $57.67^{d}$ & $57.78^{d}$ & $414.67^{h}$ & $409.57^{i}$ & $47.76^{\mathrm{cd}}$ & $45.76^{\mathrm{cd}}$ & $1.19^{\mathrm{e}}$ & $1.16^{d}$ & $42.78^{h}$ & $44.54^{9}$ & $7.16^{c}$ & $6.87^{c}$ & $0^{a}$ & $0^{\mathrm{a}}$ \\
\hline RS1 & $35.56^{\mathrm{b}}$ & $34.65^{\mathrm{ab}}$ & $160.56^{\mathrm{e}}$ & $161.44^{e f}$ & $16.67^{\mathrm{a}}$ & $13.43^{\mathrm{a}}$ & $0.59^{d}$ & $0.43^{c d}$ & $14.45^{\mathrm{e}}$ & $13.76^{\mathrm{e}}$ & $1.56^{\mathrm{a}}$ & $1.32^{\mathrm{a}}$ & $87.34^{9}$ & $89.76^{f}$ \\
\hline RS2 & $34.45^{\mathrm{ab}}$ & $35.45^{\mathrm{ab}}$ & $158.67^{\mathrm{abc}}$ & $156.38^{\mathrm{cd}}$ & $15.54^{\mathrm{a}}$ & $15.87^{\mathrm{a}}$ & $0.48^{\mathrm{ab}}$ & $0.54^{\mathrm{ab}}$ & $15.45^{f}$ & $14.45^{f}$ & $1.49^{\mathrm{a}}$ & $1.45^{\mathrm{a}}$ & $88.34^{f}$ & $90.43^{9}$ \\
\hline RS3 & $35.58^{\mathrm{ab}}$ & $33.36^{\mathrm{ab}}$ & $163.43^{\mathrm{de}}$ & $160.12^{d}$ & $15.34^{\mathrm{a}}$ & $13.56^{\mathrm{a}}$ & $0.46^{\mathrm{a}}$ & $0.56^{\mathrm{abc}}$ & $14.21^{\mathrm{e}}$ & $13.43^{\mathrm{e}}$ & $1.66^{\mathrm{a}}$ & $1.32^{\mathrm{a}}$ & $87.67^{\mathrm{ef}}$ & $87.56^{f}$ \\
\hline RS4 & $37.43^{\mathrm{ab}}$ & $36.87^{\mathrm{ab}}$ & $159.98^{\mathrm{abc}}$ & $157.87^{\mathrm{bc}}$ & $16.92^{\mathrm{a}}$ & $15.66^{\mathrm{a}}$ & $0.54^{\mathrm{abc}}$ & $0.43^{\mathrm{a}}$ & $13.34^{\text {de }}$ & $12.87^{\mathrm{ab}}$ & $1.57^{\mathrm{a}}$ & $1.55^{\mathrm{a}}$ & $87.45^{\mathrm{ef}}$ & $85.44^{d}$ \\
\hline RS5 & $33.57^{\mathrm{a}}$ & $32.69^{\mathrm{a}}$ & $150.86^{\mathrm{cd}}$ & $148.55^{d}$ & $15.25^{\mathrm{a}}$ & $13.43^{\mathrm{a}}$ & $0.46^{d}$ & $0.41^{\mathrm{abc}}$ & $9.65^{\mathrm{ab}}$ & $12.34^{\mathrm{e}}$ & $1.38^{\mathrm{a}}$ & $1.57^{\mathrm{a}}$ & $89.48^{\mathrm{fg}}$ & $87.57^{g h}$ \\
\hline RS6 & $33.76^{\mathrm{b}}$ & $35.54^{\mathrm{b}}$ & $154.78^{\mathrm{ab}}$ & $154.66^{d}$ & $15.56^{\mathrm{a}}$ & $16.33^{\mathrm{a}}$ & $0.48^{b c}$ & $0.43^{\mathrm{a}}$ & $14.34^{\text {de }}$ & $14.67^{\mathrm{de}}$ & $1.47^{\mathrm{a}}$ & $1.43^{\mathrm{a}}$ & $86.87^{e}$ & $86.33^{9}$ \\
\hline RS7 & $34.54^{\mathrm{ab}}$ & $37.12^{\mathrm{ab}}$ & $156.45^{b c}$ & $159.34^{\mathrm{cd}}$ & $15.87^{\mathrm{a}}$ & $13.58^{\mathrm{a}}$ & $0.53^{b c}$ & $0.47^{b c}$ & $9.98^{\mathrm{a}}$ & $17.98^{f}$ & $1.47^{\mathrm{a}}$ & $1.76^{\mathrm{a}}$ & $88.66^{f}$ & $89.66^{9}$ \\
\hline RS8 & $34.87^{\mathrm{a}}$ & $34.65^{\mathrm{ab}}$ & $155.87^{\mathrm{ab}}$ & $155.65^{\mathrm{ab}}$ & $15.68^{\mathrm{a}}$ & $14.65^{a}$ & $0.51^{\mathrm{abc}}$ & $0.56^{\mathrm{abc}}$ & $12.64^{\mathrm{cd}}$ & $12.54^{\mathrm{abc}}$ & $1.57^{\mathrm{a}}$ & $1.69^{\mathrm{a}}$ & $87.56^{\text {ef }}$ & $85.34^{d}$ \\
\hline RS9 & $35.56^{\mathrm{b}}$ & $35.34^{\mathrm{b}}$ & $155.57^{b}$ & $157.23^{b c}$ & $14.89^{\mathrm{a}}$ & $13.82^{\mathrm{a}}$ & $0.58^{\mathrm{bcd}}$ & $0.45^{\mathrm{b}}$ & $11.23^{\mathrm{bc}}$ & $13.23^{\mathrm{cd}}$ & $1.62^{\mathrm{a}}$ & $1.54^{\mathrm{a}}$ & $86.43^{f}$ & $87.87^{e}$ \\
\hline RS10 & $33.66^{\mathrm{ab}}$ & $32.33^{\mathrm{ab}}$ & $158.32^{\mathrm{abc}}$ & $155.89^{b}$ & $15.98^{\mathrm{a}}$ & $15.69^{\mathrm{a}}$ & $0.59^{c d}$ & $0.54^{b c}$ & $12.78^{\mathrm{de}}$ & $14.33^{\mathrm{e}}$ & $1.57^{\mathrm{a}}$ & $1.65^{\mathrm{a}}$ & $88.89^{f}$ & $88.56^{\mathrm{ef}}$ \\
\hline T4 & $75.23^{e}$ & $69.89^{\mathrm{ef}}$ & $651.23^{i}$ & $632.66^{i j}$ & $46.56^{d}$ & $47.89^{c d}$ & $1.40^{f}$ & $1.27^{f}$ & $53.98^{i j}$ & $50.57^{i}$ & $7.39^{c}$ & $7.89^{c}$ & $0^{\mathrm{a}}$ & $0^{a}$ \\
\hline T8 & $76.08^{e}$ & $68.76^{f}$ & $665.54^{j}$ & $672.27^{j}$ & $51.11^{d}$ & $49.43^{d}$ & $1.41^{f}$ & $1.41^{\mathrm{h}}$ & $54.34^{j}$ & $49.33^{9}$ & $7.53^{c}$ & $8.12^{d}$ & $0^{a}$ & $0^{a}$ \\
\hline $\mathrm{RS}+\mathrm{T} 4$ & $47.87^{c}$ & $46.88^{c}$ & $389.76^{\dagger}$ & $378.78^{9}$ & $35.49^{b}$ & $31.27^{\mathrm{bc}}$ & $1.17^{\mathrm{e}}$ & $1.14^{h}$ & $39.12^{9}$ & $36.68^{h}$ & $6.67^{b}$ & $7.14^{\mathrm{cd}}$ & $37.27^{c}$ & $39.71^{d}$ \\
\hline $\mathrm{RS}+\mathrm{T} 8$ & $49.89^{\mathrm{cd}}$ & $45.76^{\mathrm{cd}}$ & $395.57^{9}$ & $381.91^{\mathrm{h}}$ & $36.87^{b}$ & $32.62^{c}$ & $1.19^{\mathrm{e}}$ & $1.12^{\mathrm{e}}$ & $38.98^{\mathrm{g}}$ & $38.43^{g h}$ & $6.89^{b}$ & $6.98^{b c}$ & $35.58^{b}$ & $38.67^{c}$ \\
\hline
\end{tabular}

Means of three replications, followed by the letters significantly different according to Duncan's multiple range tests (DMRT). Values with different alphabetical (a-j) superscripts in a column significantly different $(P \leq 0.05)$

RS Ralstonia solanacearum, T4 and T8 T. asperellum isolates, BH Bhoomishettihalli, MH Madanahalli

The treatment of T. asperellum (T4 and T8) on the pathogen-infected plants showed significant increase in overall plant growth, including plant height, fresh weight, dry weight stem growth, and fruits per plant (Tables 1 and 2). The treatment of T. asperellum T4 increased plant height, fresh weight, dry weight, stem growth, and fruits per plant by $14.69 \mathrm{~cm}, 225.79 \mathrm{~g}$, $18.83 \mathrm{~g}, 0.77 \mathrm{~cm}$, and 28.37 fruits/plant, respectively in $\mathrm{BH}$ plot as compared with the diseased control and by $11.7 \mathrm{~cm}, 225.78 \mathrm{~g}, 20.79 \mathrm{~g}, 0.64 \mathrm{~cm}$, and 28.67 fruits/ plant respectively in $\mathrm{MH}$ plot as compared with the diseased control. The treatment of T. asperellum T8 increased plant height, fresh weight, dry weight, stem growth, and fruits per plant by $15.47 \mathrm{~cm}, 231.28 \mathrm{~g}$,
$19.46 \mathrm{~g}, 0.79 \mathrm{~cm}$, and 29.29 fruits/plant, respectively, in $\mathrm{BH}$ plot as compared with diseased control and by $11.33 \mathrm{~cm}, 232 \mathrm{~g}, 20.43 \mathrm{~g}, 0.66 \mathrm{~cm}$, and 29.35 fruits/plant respectively in $\mathrm{MH}$ plot as compared with diseased control (Table 1). In year 2015, the disease incidence in untreated control plots was nil in both plots. In $R$. solanacearum-infected $\mathrm{BH}$ and $\mathrm{MH}$ plots, it ranged from 86.43 to $89.48 \%$ and 85.34 to $90.43 \%$, respectively. $T$. asperellum-treated plots showed an average of 36.43 and $39.19 \%$ disease incidence in $\mathrm{BH}$ and $\mathrm{MH}$ plots, respectively. The $T$. asperellum treatment decreased the disease incidence by $50.69 \%(\mathrm{RS}+\mathrm{T} 4)$ and $52.38 \%(\mathrm{RS}+\mathrm{T} 8)$ in $\mathrm{BH}$ and $48.18 \%(\mathrm{RS}+\mathrm{T} 4)$ and $49.22 \%(\mathrm{RS}+\mathrm{T} 8)$ in $\mathrm{MH}$ plots, respectively. The tomato yield in untreated control

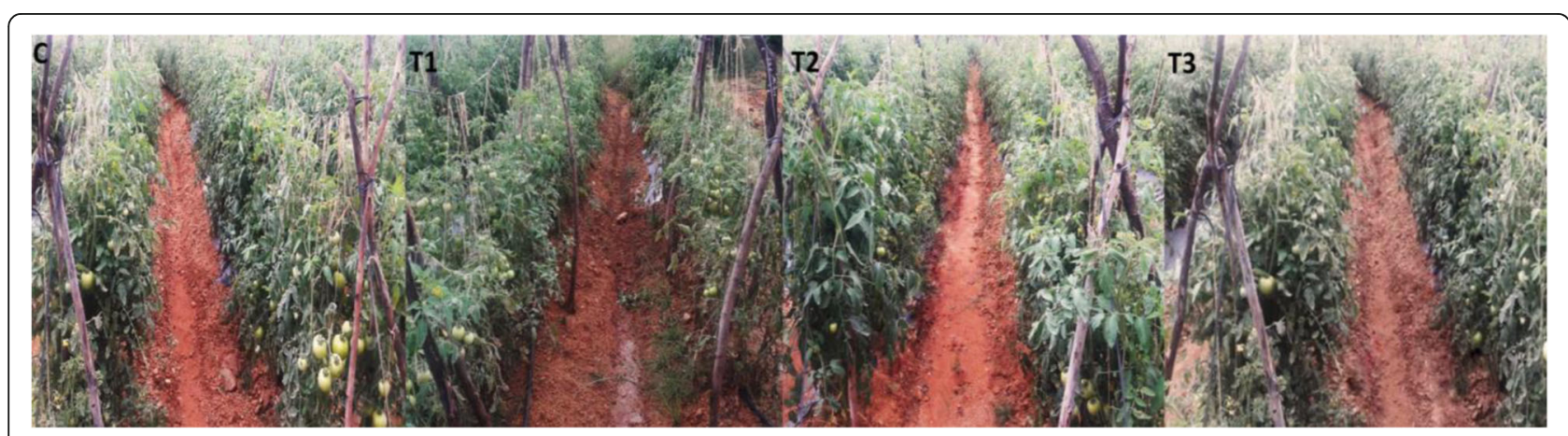

Fig. 1 Biocontrol of bacterial wilt of tomato under field conditions using T. asperellum isolates. Untreated control plants (C), plants inoculated with $R$. solanacearum alone (T1), plants inoculated with T. asperellum alone (T2), and plants inoculated with T. asperellum and challenged with $R$. solanacearum (T3) 
plot of $\mathrm{BH}$ was $7.16 \mathrm{t} / \mathrm{ha}$ and $6.87 \mathrm{t} / \mathrm{ha}$ in $\mathrm{MH}$ plot. The tomato yield in $R$. solanacearum-infected $\mathrm{BH}$ plot was about 1.38 to $1.66 \mathrm{t} /$ ha and 1.32 to $1.76 \mathrm{t} /$ ha in $\mathrm{MH}$ plot. T. asperellum isolate (T4 and T8)-treated plots yielded an average of 7.39 and $7.53 \mathrm{t} / \mathrm{ha}$ in $\mathrm{BH}$ and of 7.89 and $8.12 \mathrm{t} /$ ha of tomatoes in $\mathrm{MH}$, respectively. Thus, tomato yield increased by an average of 3.22 and $5.16 \%$ in $\mathrm{BH}$ and 14.85 and $18.20 \%$ in $\mathrm{MH}$ at $\mathrm{T} 4$ and $\mathrm{T} 8$ treatments, respectively as compared with the untreated control plots (Fig. 1). Plots challenge inoculated with $R$. solanacearum and treated with T4 and T8 yielded an average of 6.67 and $6.89 \mathrm{t} / \mathrm{ha}$ in $\mathrm{BH}$ and an average of 7.14 and $6.98 \mathrm{t} / \mathrm{ha}$ in $\mathrm{MH}$ plots, respectively. T. asperellum ( $\mathrm{T} 4$ and $\mathrm{T} 8$ ) treatment enhanced the tomato yield by $5.29 \mathrm{t} / \mathrm{ha}$ and $5.51 \mathrm{t} / \mathrm{ha}$ in $\mathrm{BH}$ and $5.82 \mathrm{t} / \mathrm{ha}$ and $5.66 \mathrm{t} / \mathrm{ha}$ in $\mathrm{MH}$, respectively when compared with $R$. solanacearum-treated plots (Tables 1 and 2).

The treatment of $T$. asperellum $\mathrm{T} 4$ increased plant height, fresh weight, dry weight, stem growth, and fruits per plant by $14.3 \mathrm{~cm}, 238.9 \mathrm{~g}, 20.34 \mathrm{~g}, 0.71 \mathrm{~cm}$, and 29.47 fruits/plant in $\mathrm{BH}$ plot as compared with diseased control and by $14.19 \mathrm{~cm}, 230.24 \mathrm{~g}, 17.84 \mathrm{~g}, 0.73 \mathrm{~cm}$, and 24.34 fruits/plant in $\mathrm{MH}$ plot, respectively. The treatment of T. asperellum T8 increased plant height, fresh weight, dry weight, stem growth, and fruits per plant by $16.32 \mathrm{~cm}, 244.71 \mathrm{~g}, 21.62 \mathrm{~g}, 0.73 \mathrm{~cm}$, and 29.33 fruits/plant in BH plot and by $13.07 \mathrm{~cm}, 233.36 \mathrm{~g}$, $19.19 \mathrm{~g}, 0.71 \mathrm{~cm}$, and 26.09 fruits/plant in $\mathrm{MH}$ plot, respectively, as compared to diseased control (Table 2).

Obtained results showed the induction of plant growth, increased tomato yield and reduced wilt incidence under field conditions upon soil treatment with T. asperellum. This outcome supports the report of Watanabe et al. (2007) who reported the management of disease by $T$. asperellum. The root colonization is a successful major requirement for the useful effects of Trichoderma spp. on plants not only concerning antagonistic behavior and increase in plant growth but also for inducing systemic resistance (Rubio et al. 2014). Trichoderma spp. have been previously demonstrated as efficient $T$. asperellum for the control of $M$. phaseolina in melon, corn, eggplant, sorghum, and chickpea (Manjunatha et al. 2013) and for the control of F. solani in beans, chili, and peanuts (Qualhato et al. 2013). Different studies on applications of Trichoderma spp. in farming practices as biological control agents, biofertilizers, and soil amendments for the control of plant pathogens and crop development in several crop plants have been well established. Trichoderma is accomplished of colonizing farmyard manure, and therefore, application of colonized FYM to the soil is more suitable and helpful. This is the mainly successful method of application of Trichoderma, particularly for the control of soilborne diseases (Hamed et al. 2015).

\section{Biochemical analysis}

The present results showed that the isolates of $T$. asperellum significantly induced maximum levels of defense enzyme activities in tomato leaves challenged with pathogen, compared with uninoculated tomato plants. Therefore, the present study revealed that $T$. asperellum exhibited significantly induced POX, PPO, PAL, $\beta$-1,3-glucanase, and total phenolic contents in plants challenged with $R$. solanacearum in tomato plants (Figs. 2, 3, 4, 5, and 6). The native gel electrophoresis also indicated the induction of isoforms in POX and PPO. Increase in activity and accumulation of systemic resistance enzymes also depends on the plant genotype, physiological conditions and the type of pathogen. Synthesis of defense chemicals against pathogens is triggered by a series of morphological and biochemical changes initiated by specific strains of fungi (Siva Prasad et al. 2013). Therefore, treatment of tomato seedlings with $T$. asperellum isolates induced POX, PAL PPO, $\beta$-1,3-glucanase, and total phenolic contents in plants infected with $R$. solanacearum. At 12 days after inoculation, the significantly increased POX activity was observed in treatment with $T$. asperellum isolates upon challenge inoculation with $R$. solanacearum and declined thereafter in all the treatments. Plants treated with $T$. asperellum alone also showed enhanced activity as compared with $R$. solanacearum treated and untreated control (Fig. 2). POX is a component of an early response in plants to pathogen infection and plays a key role in the biosynthesis of lignin, which limits the extent of pathogen spread (Vidhyasekaran 2008). When POX level increases due to the induced systemic resistance, a quick synthesis of reactive oxygen derivatives by oxidative burst leads to cell death and inhibits pathogenic activities that were observed (Prasannath et al. 2014). Therefore, improvement of POX level on 12th day after pathogen inoculation in tomato plant leaves is considered to be the marker for the development of disease resistance against $R$. solanacearum. Obtained results were supported by earlier studies which demarcated the induction of POX in plants infected by pathogens, resulting in faster and stronger resistance against them (Surekha et al. 2014). They experimentally supported the idea that peroxidase plays a defense role against attacking pathogens (Caruso et al. 2001).

PPO activity in tomato plants treated with $T$. asperellum was significantly increased upon challenged with pathogen and reached at 14th day and declined thereafter in all the treatments (Fig. 3). It is copper containing enzymes that catalyze oxidation of hydroxy phenols to their quinone derivatives, which have antimicrobial activity (Chunhua et al. 2001). Oxidative enzymes such as POX and PPO can catalyze the formation of lignin and other oxidative phenols and contribute in the formation 


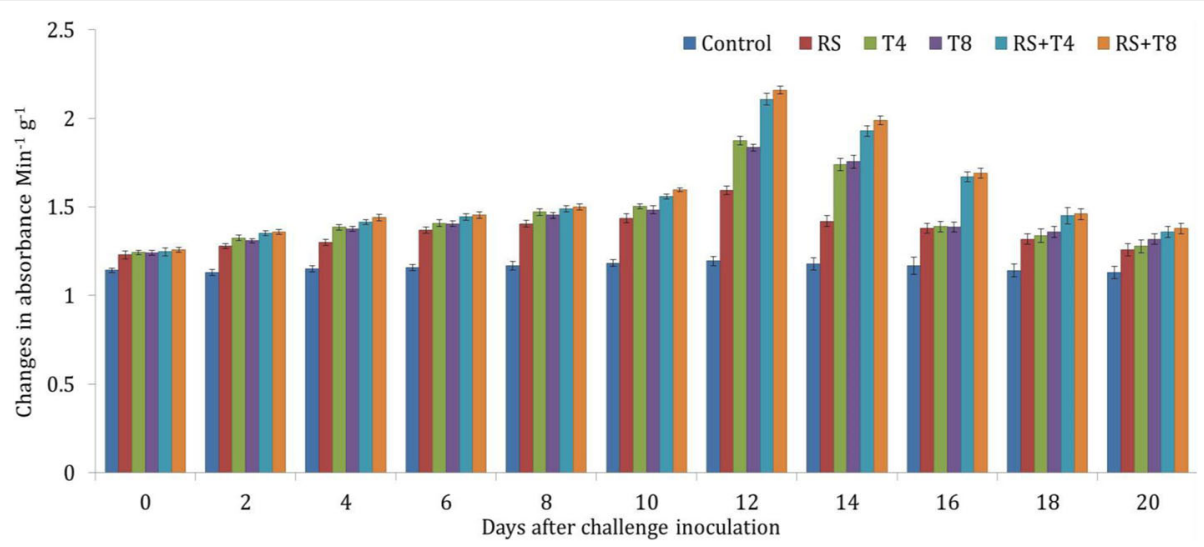

Fig. 2 Changes in peroxidase (POX) activity in tomato plants of different treatments. Mean values were three replicates. Bars represent standard error. Plants inoculated with $R$. solanacearum alone (RS); plants inoculated with T. asperellum alone (T4 and T8); T. asperellum-treated tomato plants challenged with $R$. solanacearum (RS $+\mathrm{T} 4$ and RS $+\mathrm{T} 8$ )

of defense barriers by changing the cell structure defense system that gets actuated against pathogens ( $\mathrm{Li}$ and Steffens 2002). Several potentials of PPO including general toxicity of PPO-generated quinones to pathogens and plant cells, accelerating cell death, alkylation, and reduced bioavailability of cellular proteins to the pathogen, crosslinking of quinones with protein or other phenolics, forming a physical barrier to pathogens in the cell wall and quinone redox cycling leading to $\mathrm{H}_{2} \mathrm{O}_{2}$ and other reactive oxygen species. In the present experiment, PPO activity was significantly enhanced by $T$. asperellum-treated tomato plants. Also, PPO activity level increased at 14th day after challenge inoculation and helps in disease resistance as it oxidizes the phenolic level increase during this stage to toxic molecules such as quinones leads to invasion of pathogen (Vinale et al. 2008). Activity of PAL in tomato plants treated with $T$. asperellum was significantly increased in tomato plants inoculated with $R$. solanacearum. The PAL activity reached maximum at 10th day after challenge inoculation with the pathogen and declined thereafter in all the treatments. Activity of PAL in tomato plants treated with $T$. asperellum was induced upon inoculation with pathogen (Fig. 4). Induction of defense enzymes like PAL is one of the responses of the host for treatment with Trichoderma agents. PAL is the key enzyme that is responsible for linking primary metabolism of aromatic amino acids with secondary metabolic products (Macdonald and Dcunha 2007). It is the first enzyme in phenyl propanoid metabolism and synthesis of various phenolic compounds as well as anthocyanin, biosynthesis of lignin providing mechanical strength to the plant cell wall and phytoalexins which are responsible for prevention of establishment of plant pathogens (Karthikeyan et al. 2005). In the present study, increased PAL activity and the accumulation of phenolic content

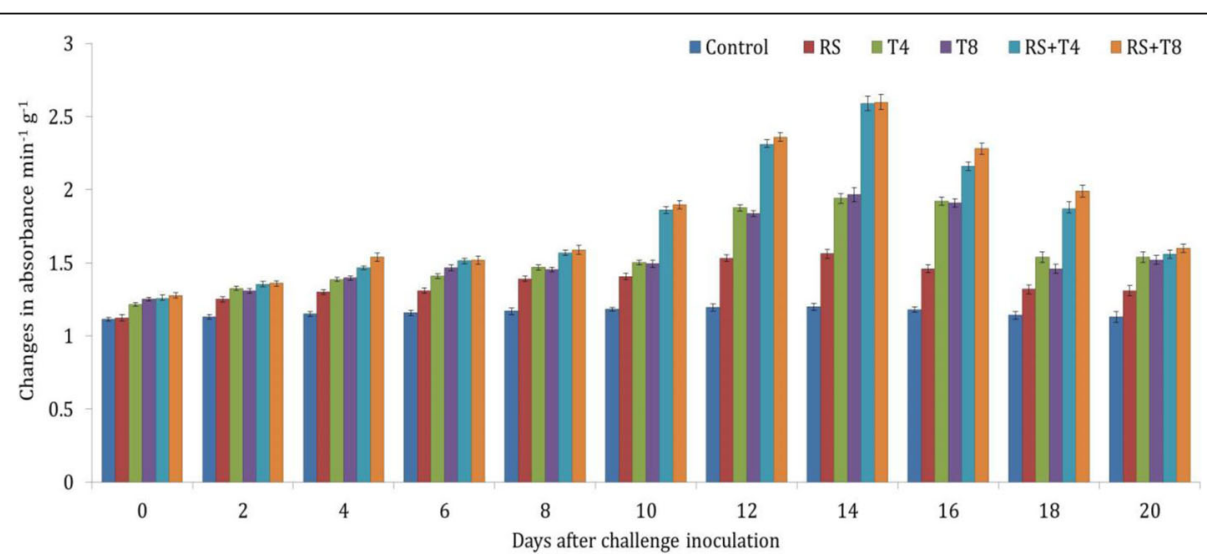

Fig. 3 Changes in polyphenol oxidase (PPO) activity in tomato plants of different treatments. Mean values were three replicates. Bars represent standard error. Plants inoculated with $R$. solanacearum alone (RS); plants inoculated with T. asperellum alone (T4 and T8); T. asperellum-treated tomato plants challenged with $R$. solanacearum (RS + T4 and RS + T8) 


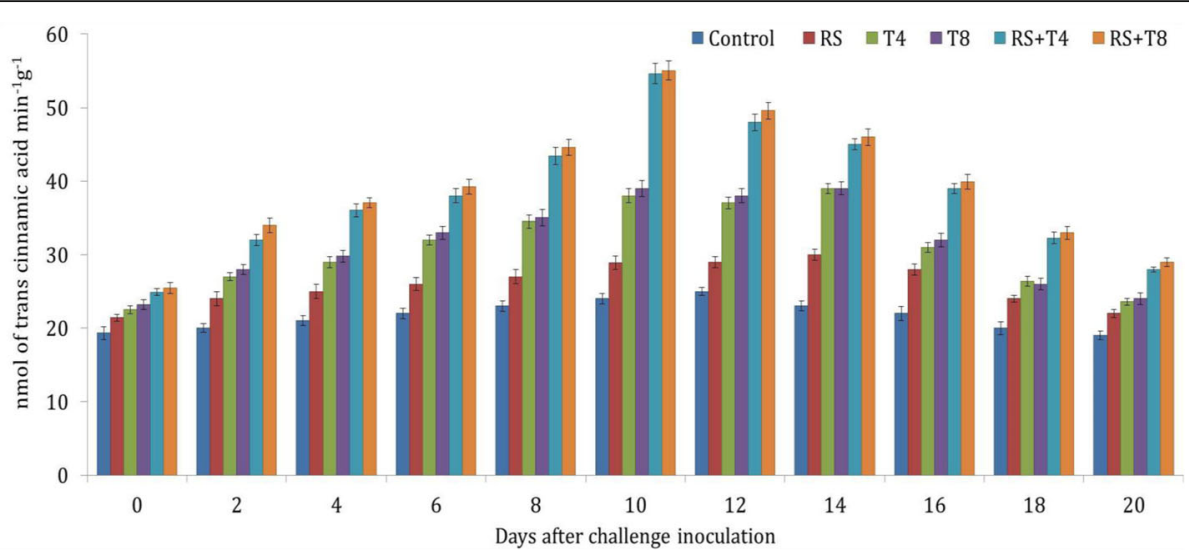

Fig. 4 Changes in phenylalanine ammonia lyase (PAL) activity in tomato plants of different treatments. Mean values were three replicates. Bars represent standard error. Plants inoculated with $R$. solanacearum alone (RS); plants inoculated with T. asperellum alone (T4 and T8); T. asperellumtreated tomato plants challenged with R. solanacearum (RS + T4 and RS + T8)

was recorded in T. asperellum isolates treated tomato plants infected with the $R$. solanacearum, apparently due to prevention of pathogen attack. Also, the T. asperellum treatment resulted in a significant increase in the PAL activity on 10th day after pathogen inoculation in tomato plants.

The $\beta-1,3$-glucanase activity reached the maximum at 12th days after inoculation with $R$. solanacearum and declined thereafter in all the treatments (Fig. 5). Improved level of pathogenesis-related PR protein such as $\beta$-1,3-glucanase activity was observed in T. asperellum-treated tomato plants and leads to disease resistance against $R$. solanacearum. It is a member of the PR protein family, known to directly destroy pathogen cell walls. Improved $\beta$-1,3-glucanase activity was observed by $T$. asperellum level up to the 12th day after pathogen inoculation, and thereafter, it starts decreasing leading to disease resistance in tomato plants against $R$. solanacearum.
Similar outcomes were previously approved by Saksirirat et al. (2009) who demonstrated that the increase in PR proteins, like chitinase and $\beta$-1,3-glucanase level up to 14th day of $X$. campestris pv. vesicatoria inoculation on tomato plants, led to the leaf spot.

Accumulation of phenolics in plants pre-treated with $T$. asperellum was induced upon challenge inoculation with $R$. solanacearum. Its accumulation significantly increased on 10th days after inoculation with the pathogen and declined thereafter in all the treatments. Maximum accumulation of phenol was noticed in T. asperellum (T8) inoculated with $R$. solanacearum at 10 days when compared with the plants inoculated with the pathogen alone (Fig. 6). Minimum amounts of phenolic compounds were observed in untreated control. The development of production of phenolics, known as defense molecules of plants against plant pathogens and insects, is indicated by an increase in PAL activity in wounded

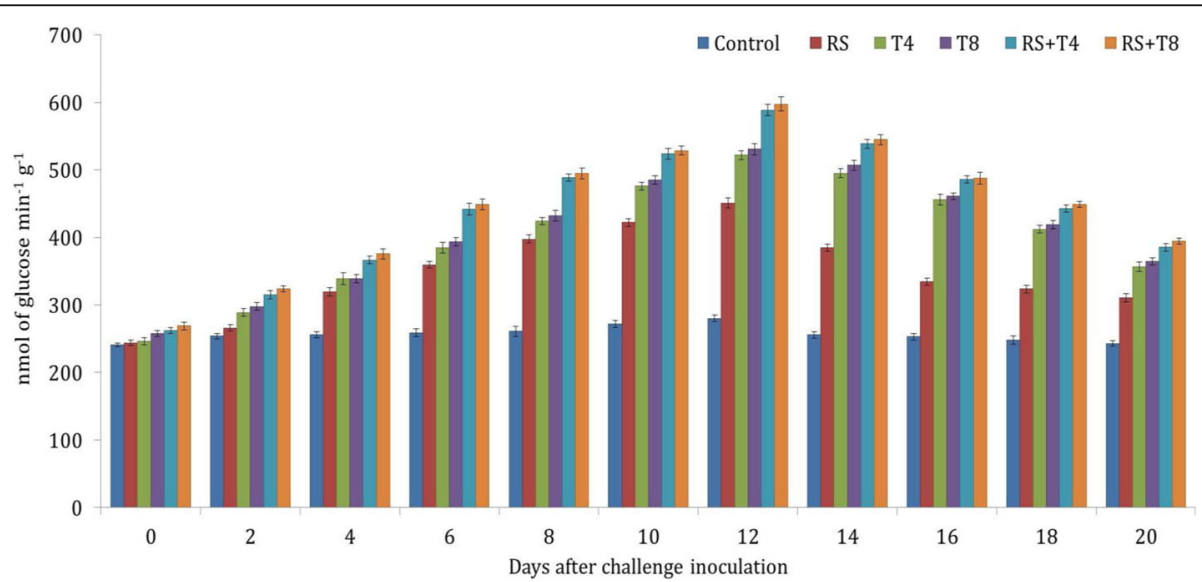

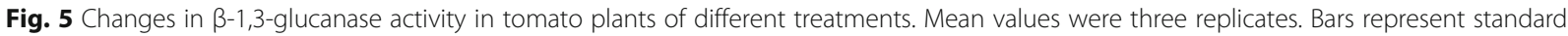
error. Plants inoculated with $R$. solanacearum alone (RS); plants inoculated with $T$. asperellum alone (T4 and T8); T. asperellum-treated tomato plants challenged with $R$. solanacearum (RS $+\mathrm{T} 4$ and $\mathrm{RS}+\mathrm{T} 8$ ) 


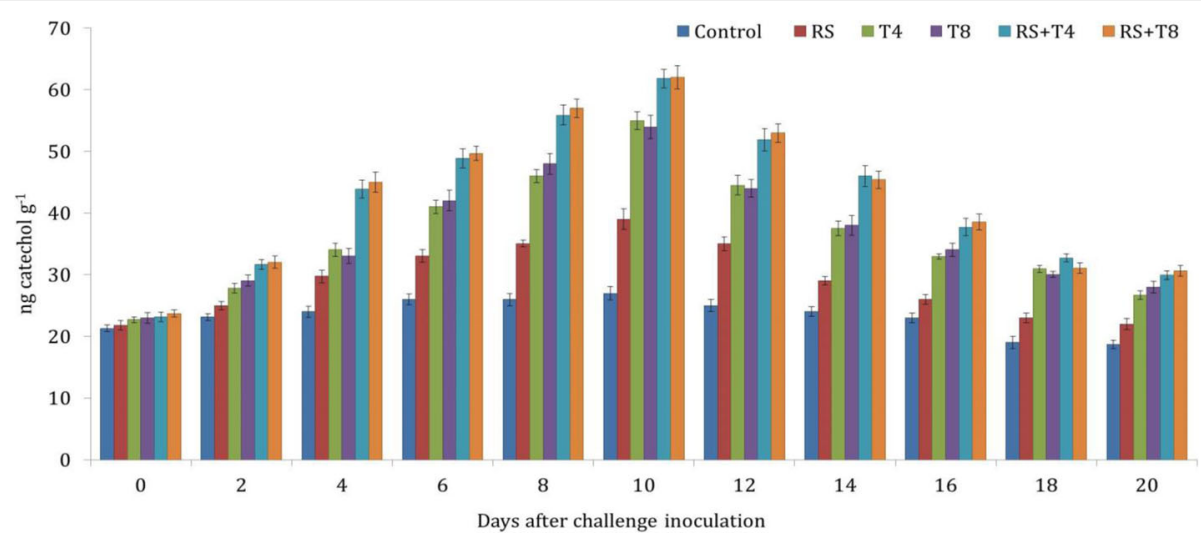

Fig. 6 Changes in total phenols in tomato plants of different treatments. Mean values were three replicates. Bars represent standard error. Plants inoculated with R. solanacearum alone (RS); plants inoculated with T. asperellum alone (T4 and T8); T. asperellum-treated tomato plants challenged with $R$. solanacearum (RS $+\mathrm{T} 4$ and $\mathrm{RS}+\mathrm{T} 8$ )

plant tissues (Bi and Felton 1995). In the present study, a high quantity of phenolic compounds was observed in the plant as compared with treated and untreated controls when tomato seedlings were treated with T. asperellum. Investigation data accumulated in the past few years have produced a completely novel understanding of the way by which these fungi interact with plants. Lopes et al. (2012) described a positive correlation between the lytic enzyme activities and the antagonism capacity of $T$. asperellum against $S$. sclerotiorum. The presence of $T$. asperellum in cucumber roots triggers the SA and JA pathways in the plant and increased peroxidase activity, hence conferring protection to cucumber plants against foliar pathogens (Segarra et al. 2007).

\section{Native PAGE analysis POX and PPO}

Native PAGE analysis revealed that POX isoforms designated as POX1 to POX8 were observed in T. asperellum-treated tomato leaf tissues inoculated with the $R$. solanacearum and the expression of isoforms POX3, POX4, POX6, and POX7 showed higher induction in tomato plants inoculated with the pathogen compared with other treatments under field conditions (Fig. 7a). Similarly, five isoforms of PPO (PPO1 to PPO5) were showed in T. asperellum-treated plants after inoculation with $R$. solanacearum, whereas in the controls less intensity was noticed. A higher induction of PPO was observed in plants pretreated with T. asperellum inoculated with $R$. solanacearum (Fig. 7b). The increased

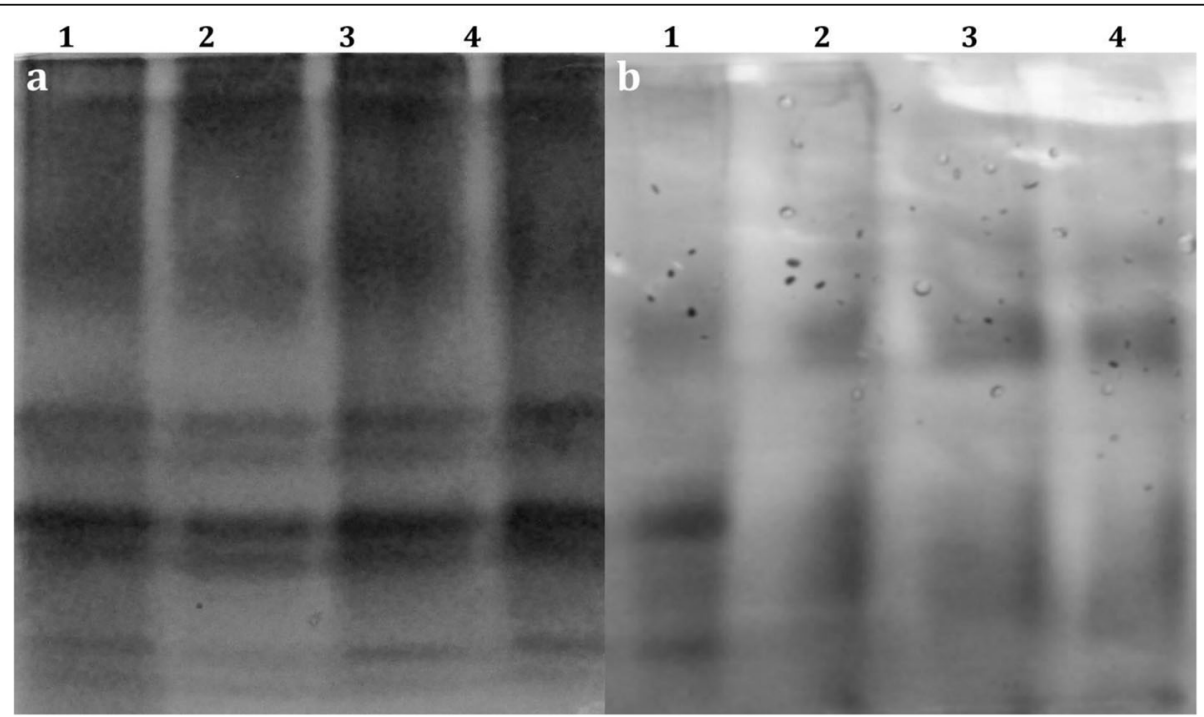

Fig. 7 Native PAGE profiles of (a) POX and (b) PPO, induced in response to challenge with $R$. solanacearum. Lane $1-$ untreated control (C), lane $2-R$. solanacearum alone (T1), lane 3-T. asperellum alone (T2), and lane 4-inoculated with T. asperellum and challenged with R. solanacearum (T3) 
expression of isoforms of POX and PPO might be responsible for reduced disease incidence.

\section{Conclusions}

The present study showed that biocontrol capacity and biochemical characterization of induced systemic resistance by $T$. asperellum against $R$. solanacearum in tomato and comprehends the role of defense enzymes in developing disease resistance under field conditions. The two $T$. asperellum isolates recorded efficient inhibition against $R$. solanacearum and increased yield of tomatoes under field experiments. The role of T. asperellum is as BCA in the induction of a series of defense responses such as accumulation of phenols and induction of POX, PPO, and PAL enzymes involved in phenylpropanoid metabolism and of PR protein ( $\beta$-1,3-glucanase) in response to treatment with the biocontrol agent. In this regard, it is recommended the use of $T$. asperellum assessment to the actions within disease management framework is reasonable, provided that long term induced resistance and should be developed as a sustainable and environmental friendly approach.

\section{Acknowledgements}

The authors are thankful to the University Grants Commission, Government of India, New Delhi, for providing UGC-BSR Meritorious fellowship for the first author. The authors also like to thank the Chairman, Department of Microbiology and Biotechnology, Bangalore University, Bangalore, for providing the facilities for this investigation.

\section{Funding}

This study received funding from the University Grants Commission, Government of India, New Delhi.

\section{Availability of data and materials}

All datasets on which conclusions of the study have been drawn are presented in the main manuscript.

\section{Authors' contributions}

NK conceived the idea, suggested the point of research, designed the experimental work, conducted the experiments, and wrote the manuscript. SK worked on the management of the article, statistical analysis of data, and critical revision. SCN, SRN, and SC participated in the experiments' design and coordination. All authors read and approved the final manuscript.

\section{Ethics approval and consent to participate}

Not applicable.

\section{Consent for publication}

Not applicable.

\section{Competing interests}

The authors declare that they have no competing interests.

\section{Publisher's Note}

Springer Nature remains neutral with regard to jurisdictional claims in published maps and institutional affiliations.

\section{Author details}

${ }^{1}$ Department of Studies in Biotechnology, University of Mysore, Manasagangotri, Mysore, Karnataka 570 006, India. ²Department of Microbiology and Biotechnology, Bangalore University, Jnanabharathi Campus, Bangalore, Karnataka 560 056, India. ${ }^{3}$ Department of Microbiology, Field Marshal K. M. Cariappa College, Constituent College of Mangalore University, Madikeri, Kodagu, Karnataka, India.
Received: 24 April 2018 Accepted: 23 July 2018

Published online: 31 July 2018

\section{References}

Abdelrahman M, Abdel-Motaal F, El-Sayed M, Jogaiah S, Shigyo M, Ito SI, Tran LS (2016) Dissection of Trichoderma longibrachiatum-induced defense in onion (Allium cepa L.) against Fusarium oxysporum f. sp. cepa by target metabolite profiling. Plant Sci 246:128-138

Alka, Patil RK, Prajapati BK (2017) Effect of Trichoderma Spp. and its culture filtrate antagonists on growth and management of Rhizopus rot of tomato fruit in vitro and in vivo. J Pharmacogn Phytochem 6(4):394-398

Avinash P, Umesha S, Raghava S, Shirin M (2016) Discrimination of Ralstonia solanacearum isolates by genetic signatures produced by single-strand conformation polymorphism and low-stringency single specific primer PCR analysis. Afr J Microbiol Res 10:1128-1139

Bi JL, Felton GW (1995) Foliar oxidative and insect herbivory: primary compounds, secondary metabolites, and reactive oxygen species as components of induced resistance. J Chem Ecol 21:1511-1530

Caruso C, Chilosi G, Leonardi L, Bertini L, Magro P, Buonocore V, Caporale C (2001) A basic peroxidase from wheat kernel with antifungal activity. Phytochemistry 72 : 248-254

Chunhua S, Ya D, Bingle X, Xiao L, Yonshu X, Qinguang L (2001) The purification and spectral properties of PPO I from Nicotianan tababcum. Plant Mol Biol 19:301-314

Dalal NR, Dalal SR, Dalal V, Golliwar G, Khobragade RI (1999) Studies on grading and prepackaging of some bacterial wilt resistant brinjal (Solanum melongena L.) varieties. J Soils Crops 9:223-226

Dickerson DP, Pascholati SF, Hagerman AE, Butler LG, Nicholson RL (1984) Phenylalanine ammonia lyase and hydroxycinnamate: CoA ligase in maize mesocotyls inoculated with Helminthosporium maydis or Helminthosporium carbonum. Physiol Plant Pathol 25:111-123

Elsharkawy MM, Shimizu M, Takahashi H, Hyakumachi M (2012) Induction of systemic resistance against cucumber mosaic virus by Penicillium simplicissimum GP17-2 in Arabidopsis and tobacco. Plant Pathol 61:964-976

Hamed ER, Awad HM, Ghazi EA, El-Gamal NG, Shehata HS (2015) Trichoderma asperellum isolated from salinity soil using rice straw waste as biocontrol agent for cowpea plant pathogens. J Appl Pharm Sci 5:091-098

Hammerschmidt R, Nuckles EM, Kucm J (1982) Association of enhanced peroxidase activity with induced systemic resistance of cucumber to Colletotrichum lagenarium. Physiol Plant Pathol 20:73-82

Huang XQ, Chen LH, Ran W, Shen OR, Yang XM (2011) Trichoderma sp. strain SQR-T37 and its bioorganic fertilizer could control Rhizoctonia solani damping off disease in cucumber seedlings mainly by the mycoparasitism. Appl Microbiol Biotechnol 91:741-755

Jayaraman KS, Ramanuja MN, Vijayarahavan PK, Vaidyanathan CS (1987) Oxidative enzyme in pearl millet. Food Chem 24:203

Ji XL, Lu GB, Gai YP, Zheng CC, Mu ZM (2008) Biological control against bacterial wilt and colonization of mulberry by an endophytic Bacillus subtilis strain. FEMS Microbiol Ecol 65:565-573

Karthikeyan M, Jayakumar V, Radhika K, Bhaskaran R, Velazhahan R, Alice D (2005) Induction of resistance in host against the infection of leaf blight pathogen (Alternaria palandui) in onion (Allium cepa var aggregatum). Indian J Biochem Biophys 42(6):371-377

Kelman A (1954) The relationship of pathogenicity of Pseudomonas solanacearum to colony appearance on a tetrazolium medium. Phytopathology 44:639-695

Keswani C, Bisen K, Singh V, Sarma BK, Singh HB (2016) Formulation technology of biocontrol agents: present status and future prospects. In: Arora NK, Mehnaz S, Balestrini R (eds) Bioformulations: for sustainable agriculture. Springer, India, pp 35-52

Laemmli UK (1970) Cleavage of structural proteins during the assembly of the head of bacteriophage T4. Nature 227:680-685

Li L, Steffens JC (2002) Overexpression of polyphenol oxidase in transgenic tomato plants results in enhanced bacterial disease resistance. Planta 215:239-247

Li YT, Hwang SG, Huang YM, Huang CH (2017) Effects of Trichoderma asperellum on nutrient uptake and Fusarium wilt of tomato. Crop Prot 1(8). doi: https:// doi.org/10.1016/j.cropro.2017.03.021

Ling N, Xue C, Huang QW, Yang XM, Xu YC, Shen QR (2010) Development of amode of application of bioorganic fertilizer for improving the biocontrol efficacy to Fusarium wilt. BioControl 55:673-683 
Liu YX, Shi JX, Feng YG, Yang XM, Li X, Shen QR (2012) Tobacco bacterial wilt can be biologically controlled by the application of antagonistic strains in combination with organic fertilizer. Biol Fertil Soils 47:239-248

Lopes FAC, Stendorff AS, Geraldine AM, Brandao RS, Monteiro VN, Junior ML, Coelho ASG, Ulhon CJ, Silva RN (2012) Biochemical and metabolic profiles of Trichoderma strains isolated from common bean crops in the Brazilian Cerrado, and potential antagonism against Sclerotinia sclerotiorum. Fungal Biol 116:815-824

Lowry OH, Rosebrough NH, Farr AL, Randall RJ (1951) Protein measurement with the folin phenol reagent. J Biol Chem 193:265-275

Macdonald MJ, Dcunha GB (2007) A modern view of phenylalanine ammonia lyase. Biochem Cell Biol 85:273-282

Manjunatha SV, Naik MK, Khan MFR, Goswami RS (2013) Evaluation of bio-control agents for management of dry root rot of chickpea caused by Macrophomina phaseolina. Crop Prot 45:147-150

Mayer AM, Harel E, Shaul RB (1965) Assay of catechol oxidase a critical comparison of methods. Phytochemistry 5:783-789

Nadolny L, Sequeira L (1980) Increases in peroxidase activities are not directly involved in induced resistance in tobacco. Physiol Plant Pathol 16:1-8

Narasimha Murthy K, Malini M, Fazilath U, Soumya KK, Chandra NS, Niranjana SR, Srinivas C (2016) Lactic acid bacteria mediated induction of defense enzymes to enhance the resistance in tomato against Ralstonia solanacearum causing bacterial wilt. Sci Hortic 207:183-192

Narasimha Murthy K, Nirmala Devi D, Srinivas C (2013) Efficacy of Trichoderma asperellum against Ralstonia solanacearum under greenhouse conditions. Ann Plant Sci 2:342-350

Narasimha Murthy K, Srinivas C (2012) In vitro screening of bioantagonistic agents and plant extracts to control bacterial wilt (Ralstonia solanacearum) of tomato (Lycopersicon esculentum). J Agric Technol 8:999-1015

Pan SQ, Ye XS, Kuc J (1991) A technique for detection of chitinase, beta-1, 3glucanase, and protein patterns after a single separation using poly-acrylamide gel electrophoresis or isoelectro focusing. Phytopathology 81:970-974

Prasannath K, Dharmadasa KNP, De Costa DM, Hemachandra KS (2014) Variations of incidence, types of virus diseases and insect vector populations of tomato (Solanum lycopersicum L.), grown in different agro- ecological regions of Sri Lanka under two crop management systems. Trop Agric. Res 25(3):376-395

Qualhato TF, Lopes FA, Steindorff AS, Brandao RS, Jesuino RS, Ulhoa CJ (2013) Mycoparasitism studies of Trichoderma species against three phytopathogenic fungi: evaluation of antagonism and hydrolytic enzyme production. Biotechnol Lett 35:1461-1468

Ramesh R, Achari GA, Gaitonde S (2014) Genetic diversity of Ralstonia solanacearum infecting solanaceous vegetables from India reveals the existence of unknown or newer sequevars of Phylotype I strains. Eur J Plant Pathol 140:543-562

Ran LX, Liu CY, Wu GJ, Van Loon LC, Bakker PAHM (2005) Suppression of bacterial wilt in Eucalyptus urophylla by fluorescent Pseudomonas spp. in China. Biol Control 32:111-120

Rojo FG, Reynoso MM, Sofia MF, Chulze N, Torres AM (2007) Biological control by Trichoderma species of Fusarium solani causing peanut brown root rot under field conditions. Crop Prot 26:549-555

Rubio MB, Quijada NM, Pérez E, Domínguez S, Monte E, Hermosa R (2014) Identifying beneficial qualities of Trichoderma parareesei for plants. Appl Environ Microbiol 80:1864-1873

Saksirirat W, Chareerak P, Bunyatrachata W (2009) Induced systemic resistance of biocontrol fungus, Trichoderma spp. against bacterial and gray leaf spot in tomatoes. Asian J Food Agro-Ind 2:S99-S104

Satish KS, Abhay KP (2016) Biological spectrum of Trichoderma harzianum Rifai isolates to control fungal diseases of tomato (Solanum lycopersicon L.). Arch. Phytopathol. Plant Prot 49:507-521

Schonfeld J, Gelsomino A, Overbeek LS, Gorissen A, Smalla K, Elsas JD (2003) Effects of compost addition and simulated solarisation on the fate of Ralstonia solanacearum biovar 2 and indigenous bacteria in soil. FEMS Microbiol Ecol 43:63-74

Segarra G, Casanova E, Bellido D, Odena MA, Oliveira E, Trillas I (2007) Proteome, salicylic acid, and jasmonic acid changes in cucumber plants inoculated with Trichoderma asperellum strain T34. Proteomics 7:3943-3952

Sharma MP, Gaur A, Tanu U, Sharma OP (2004) Prospects of arbuscular mycorrhiza in sustainable management of root and soil borne diseases of vegetable crops. In: Mukerji KG (ed) Disease management of fruits and vegetables, Fruit and vegetable diseases, vol I. Kluwer Academic Publishers, Netherlands, pp 501-539
Siva Prasad B, Kamala G, Sankar Ganesh P (2013) Efficacy of Trichoderma viride to induce disease resistance and antioxidant responses in legume Vigna Mungo infested by Fusarium oxysporum and Alternaria alternata. Int J Agric Sci Res 3(2):285-294

Surekha CH, Neelapu NRR, Prasad BS, Sankar GP (2014) Induction of defense enzymes and phenolic content by Trichoderma viride in Vigna mungo infested with Fusarium oxysporum and Alternaria Alternata. Int J Agric Sci Res 4:31-40

Vanitha S, Niranjana S, Mortensen C, Umesha S (2009) Bacterial wilt of tomato in Karnataka and its management by Pseudomonas fluorescens. BioControl 54: 685-695

Vidhyasekaran P (2008) Evasion and detoxification of secondary metabolites. In: Vidhyasekaran P (ed) Fungal pathogenesis in plants and crops: molecular biology and host defense mechanisms, 2nd edn. CRC Press, Boca Raton, pp 411-467

Vinale F, Sivasithamparam K, Ghisalberti EL, Marra R, Woo SL, Lorito M (2008) Trichoderma-plant-pathogen interactions. Soil Biol Biochem 40:1-10

Watanabe S, Kunakura K, Izawa N, Nagayama K, Mitachi T, Kanamori M, Teraoka T, Arie T (2007) Mode of action of Trichoderma asperellum SKT-1, a biocontrol agent against Gibberella fujikuroi. J Pestic Sci 32:222-228

Zachow C, Berg C, Muller H, Monk J, Berg G (2016) Endemic plants harbour specific Trichoderma communities with an exceptional potential for biocontrol of phytopathogens. J Biotechnol 235:162-170

Zieslin N, Ben-Zaken R (1993) Peroxidase activity and presence of phenolic substances in peduncles of rose flower. Plant Physiol Biochem 31:333-339

\section{Submit your manuscript to a SpringerOpen ${ }^{\circ}$ journal and benefit from:}

- Convenient online submission

Rigorous peer review

- Open access: articles freely available online

- High visibility within the field

- Retaining the copyright to your article

Submit your next manuscript at $\boldsymbol{\nabla}$ springeropen.com 